\title{
TRACING COUNTERCLAIMS AGAINST DOMINANT DISCOURSES ON ETHNICITY - A FINNISH EXAMPLE
}

\author{
TIINA MÄ̈̈TTÄ, \\ MERJA LAITINEN \\ LAPLANDIJOS UNIVERSITETAS, SUOMIJA
}

To challenge ethnic stereotyping, it is important to give space to unique individual narratives, both in social work research and practice. Individually and locally specific narratives relate to the wider discussions about globalization. Focusing on individuals' everyday experiences promotes the finding of commonalities between people, which in turn promotes an inclusive approach to growing diversity.

\section{INTRODUCTION}

In this article we consider the construction of ethnic identity, from the standpoint of a relatively homogeneous society, Nordic Finland. The focus is on how identities are negotiated in daily interactions in a community setting. The Finnish example contributes one perspective to the academic discussions on relationship between subjectivity, ethnicity and professional interaction (see Park, 2005; Masocha, 2014; Young and Zubrzycki, 2011). This article, based on qualitative analysis, considers the complex identity demands that are displayed in the experiences of non-native residents. The research considered the conflict between how individuals perceive and understand themselves and the external expectations they face to exhibit signs of identification with pre-determined ethnic categories.

We are detaching the research from the rhetoric of multicultural discourse, which makes ethnic divisions appear somehow natural. When categories are pre-determined, this can erase individual differences. The unmasking of dominant discourses is central to the social constructionist approach adopted here. This approach requires the questioning of taken 
for granted knowledge and understanding that categories are historically and culturally specific. (Burr, 1995). This dynamic has implications for social work. For instance Ploesser and Mecheril (2012) make the point that social work discourses demand equality for immigrants, but when the discourses lack self-criticism they in fact reproduce inequality and binary opposites, such as us/them. Through understanding the everyday experiences of immigrants, social work can develop a genuine sensitivity to individual needs. This correlates with the wider discussions within social work about the development of user-led services and utilising experiential expertise in planning of practices (e.g. Beresford and Croft, 2001; McLaughlin, 2009; Vennik et al., 2014).

This paper focuses on the under researched implications of the construction of ethnic identity in the Finnish context. It is based on qualitative analysis that gives voice to immigrants' subjective experiences. We analyse what kind of strategies do immigrants utilise when they are encountering the onset of limitations to their identities. Narrated strategies make visible the power structures in people's everyday lives and pose questions for social work and social workers about the prejudices that lie beneath the conscious level and make an impact on the worker's own identity. The aim is to deepen knowledge about identity negotiations from a subjective viewpoint. The study contributes to the academic discourses concerning the unacknowledged privileges that representatives of majority, in particular social workers, need to be aware of (e.g. Park, 2005; Curry-Stevens, 2011; de Montigny, 2013; Masocha, 2014; Young and Zubrzycki, 2011). This article seeks to contribute to the knowledge base on the understanding of everyday mundane experiences of individuals (e.g. de Montigny, 2013; Tigervall and Hübinette, 2010).

The framework of this article lies in the discussions that relate to the social construction of cultural categories within social work as regards to identity. Understanding how non-native residents negotiate their identities in relation to the stereotypes that the majority population produces about the Other, is the focus of the analysis. We see identity categories as important markers of divisions between inclusion and exclusion and as such they are important also for social work. Social work research needs to understand resistance in order to see the construction of alternative identities as a resource, not as a threat (Juhila and Abrams, 2011). In this article the social construction of ethnic categories is bound to the Finnish socio-cultural context, which represents the cultural power of the 
majority (Hall, 1999: 53). There are approximately 5.4 million inhabitants in Finland, with the majority located in the southern regions. It is the most sparsely populated country in the European Union. Immigrants make up only around 3 per cent of the population, with Estonians and Russians forming the vast majority of foreign citizens. Swedish, Somali, Chinese, Thai, and Iraqi are the next largest nationalities. (Statistics Finland, 2013.) Because the overwhelming majority in Finland are native born residents, the country provides an interesting context for exploring the dynamics of power around the construction of ethnic identity.

The Universalist speech, located at the core of the Nordic welfare state ideology, can prevent workers from reflecting on the idea that practises are not in fact universal but based on the habits and perceptions of the majority. For example this can be seen in the tendency to perceive nonwestern women from a victim perspective. Clarke (2011b: 16) describes how framing of gendered violence in the Finnish context has xenophobic elements. These kinds of prejudices have many consequences for how people's needs are met in welfare services and social work practices. Stereotypes based on ethnicity become visible in the research that focuses on the interactions between Finnish official authorities and immigrants (Anis, 2008; Egharevba, 2011; Keskinen, 2011). Universalism can give, in a sense, a justification in creating the Other, as immigrants can be seen as essentially different from Finns as humans. As long as Finnish social workers rely on top-down expertise as regards to immigrants, they embrace wider political aspirations that aim to exclude immigrants from the processes of knowledge production. (See Keskinen, 2011; Clarke, 2011a). Suurpää (2002: 45) points out how immigrants in Finnish discourses are mainly put into a victim category, which focuses on lack. She identifies four lacks that frame immigrants in dominant discourses: lack of societal skills, lack of social skills, lack of cultural skills, and lack of moral codes. Suokonautio (2008: 20-21) discusses how the Finnish mainstream society constantly evaluates how new comers compare with what it viewed as Finnish. Those furthest from the imagined norm receive the least amount of trust and power when they raise their own concerns in their own words.

On the other hand, highlighting cultural sensitivity in the encounters can lead to re-creation of Otherness (Park, 2005). Cultural sensitivity can create the illusion, that cultural differences can be known whereas differences are infinite. (Ben-Ari and Strier, 2010: 2163.) Ethnicity plays 
a disproportionate role in the everyday lives of individuals. For example, over representation of immigrant children in child protection services has been identified and needs further exploration (e.g. Johansson, 2011; Walker, 2005). Anis (2008: 29) draws attention to an inner paradox in Finnish social work among immigrants which is that through defining what is normal it produces practises of exclusion. There is a real danger that parenting issues are explained by cultural factors (Anis, 2008: 89-90). For example, a mother's tiredness or depression may not get noticed if the social worker believes that challenges in parenting can be explained by a different culture of parenting. An interested study conducted in Sweden (Tigervall and Hübinette, 2010) illustrates how ethnic categorisation can make life difficult for adoptive parents and their children. The non-white bodies of the adoptees are consistently highlighted in the everyday interaction with the representatives of the Swedish majority.

This article is attached to the idea that local theories and practices illustrate the silent voices and experiences of vulnerable individuals and groups (e.g. Dominelli, 2012). We highlight the need for seeking and hearing different subjective voices in social work research (e.g. Juhila, 2006; Keddell, 2009). The aim of the article is to share mundane experiences that hold the greatest potential to shatter ethnic stereotypes (see Curry-Stevens, 2011).

\section{RESEARCH}

The purpose of the research was to find out how individuals that are not native residents define themselves and belonging through narratives. The incentive was to understand everyday experiences effects on individual identity construction. The informants were found using snowball sampling. It was important that participation would be entirely voluntary. If the people had been approached through an organization it might have created feelings of pressure to take part. Addressing difficult, personal topics in interview situations has been noted to provoke fear and anxiety in participants in the context of Finnish research done with immigrants (e.g. Harinen and Niemelä, 2005).

Three non-native residents participated in the research during the summer/autumn of 2012; two women and one man. One of them was in her early adulthood and two were middle-aged. Two of them were European of Western origin, one was of non-European origin. 
Finnish research ethics guidelines were adhered throughout the research and informed consent was obtained from the people involved. The information was gathered in two interview sessions that were taped with participants' permission and each interview lasted approximately two hours each. At their request, two of the participants were interviewed together: they were in a long-term relationship and had come to Finland together.

The possibility of interpreters was abandoned because of the ethical dilemmas that using interpreters can bring, it is impossible to verify that mutual understanding is reached. Therefore the language used in the interviews was English. Using Finnish could have emphasized the researcher's position as a representative of the majority, particularly if all the participants did not yet speak Finnish fluently. The two European participants were native English speakers.

The interviews were modelled on a conversation between partners whose relationship was as equal as possible. The interview method followed the principles set by Gubrium and Holstein (2003). The participants organized the telling of their stories through how they understood the notion of belonging and how they located belonging at different times in their lives, in different locations. This was an in-depth process. Analysis started by reading the taped and transcribed material as a whole, and searching for individual themes. This was done through identifying themes which appeared essential to the understanding of the narratives. We were interested in what themes were reoccurring and how strong or weak they appeared in relation to one another. The participants reflected on mundane everyday situations. Abstract hopes and dreams were also present in the sense that the participants discussed what had worked out since they arrived to Finland, and what aspirations had fell short.

In the findings, the space in which immigrants define their own identities appeared claustrophobic because of the obsession in majority discourses to point out ethnic differences, from which followed that participants' individual political opinions and choices were ignored in everyday interactions. To deal with this, the participants had developed individual ways of coping. These improvised strategies included explaining, playing with categories, engaging in conflict, withdrawal and acceptance of the role of the Other. Meanings related to Finnish culture were constantly deconstructed and re-negotiated by the research participants. It appeared 
that the strategies can only go so far. In order to succeed members of the majority have to recognize the individual. Identities cannot become complete in a vacuum because they require involvement from others.

\section{RESULTS: THE IMPROVISED EVERYDAY STRATEGIES}

Explaining takes place especially after moving to Finland but at some point one grows tired of explaining. The urgency to create categories around immigrant identities denies the individual his or her right to ambivalence. Immigrants face reoccurring situations where one is expected to justify oneself to complete strangers.

'Curiosity is about not who you are but why you are here. Are you living off the state, do you have a rich husband? Or what is your purpose, what do you want to do here and why? You are forcing the person to give an answer that the person does not even know; there are people who do not know why they are here. I could tell you reasons why I am here and thousands of reasons why I shouldn't be here. This is why this is very abstract. When people notice you are an immigrant, they say where are you from, why are you here, what is your purpose. If you say you want to study the language there is a feeling that this one just wants to live off the state. If you say you are working the person thinks, oh, she is an immigrant and she works, I am Finnish and I don't have work.'

'That is one thing people try to come to terms with, why would you want to come here? It's a struggle because we always have to explain, why we are not somewhere warm. We can explain what our motives were but is seems hard for a Finnish person to understand because they cannot see it through our eyes.'

The answers to the questions are always inevitably undesirable because of the logic of stereotyping. What makes stereotyping challenging, according to Hall (1997: 229), is that immigrants are expected to represent both binary extremes at the same time! A single individual faces accusations in the above situation of being too passive and at the same time too active. Another interesting binary representation in the above material is the request to show that one appreciates Finland but at the same time, the appreciation of Finland appears somehow implausible. Therefore showing appreciation deems the individual unreliable. The logic of stereotyping ensures that explaining is futile and only accumulates frustration. There is no possibility for a dialogue between persons, as the findings illustrate. 
Hall notes (1999: 124) that stereotypes also expose ideologies that are prevalent in the dominant culture that produces the stereotype of the Other, for example, about attitudes towards gender. The two women interviewed said they regularly were asked intimate questions, such as 'Do you have a rich husband?' Hall (1999: 83) talks about the way Europe does not always need a non-western Other. Women are still to a certain extent the Other within Europe.

Playing with categories is a light-hearted way to respond to stereotypes. The individual is aware of her position on the outside so uses it as an opportunity to express herself freely without cultural restrictions. The more you look like the majority, the less you are defined by strict binary opposites and therefore you can make your own categories.

'We are not necessarily your average English couple but get labelled as the average English couple. It is not a negative for us but it is a bonus because we are slightly eccentric and we like doing things that Finnish people don't do so with that eccentric label it enables you to have freedom actually and not be restricted by Finnish or English culture.'

The more one's looks differ from the majority, the more severe expectations become and the less room there is to manoeuvre. In the above extract the individual attaches certain freedom to being non-native. Non-westerners, on the other hand, are expected to work harder to become accepted. Horsti (2009: 80) discusses the way in which immigrants in Finland are viewed as having certain signs of Otherness, which are crucial to the dominant population so they can participate in removing these signs. Signs that signify Finnishness replace undressed signs signifying the Other.

'Many people say ok now you are going to sauna! But I go because it is cold. They think I can get used to it (sauna). Sometimes I like but not as a daily thing. The same if I am in a group, everyone is drinking, and I take a beer in my hand and people are like aaah she is drinking! This prejudice is the worst.'

Engaging in direct conflict is stressful. Huttunen (2004: 142) notes that immigrants in Finland often emphasise characteristics like hard working and quiet when they address their own identity. To challenge the system means stepping out from the submissive role that immigrants are supposed to adopt, as an unwritten rule. The demands are calmly stated, not to cause offend. 
'If I go to unemployment office, I know I need to be sitting there but when I think how I need to act; I get sweaty and start to get warm on my face. Now she is going to say something I don't agree with, how should I answer. For example in the unemployment office there is a course and they say this is what I have to have and I don't agree with that. I am very mad but I need to explain in a quiet way that I don't agree and you have to think what kind of words you are going to say, so that the other person is not going to feel offended.'

In a way, immigrants are expected to file their personal identity and accept what is given. It means placing one's own moral and intellectual compass on the shelf and succumbing to other people defining who you are and what you are capable of doing and achieving. Individuals can feel like they are becoming institutionalised.

'The problem is that you don't choose what you want to do, the unemployment office chooses for you. There are different kinds of immigrants here like refugees. And some come because of a relationship, or to work. There are a lot of people who just want to be here. What you do here doesn't depend on what you want, how your feelings are, or what are your projects. It depends on the official, the social worker, what she is thinking about you, what they think you can do. You have a lot of projects and you come here like you want to work. You want to study. You really want to be integrated. You want to make life here. But then you have to go through the unemployment office and the system. They make your life. You go to Rovala then you go to some work practice. What happens to your personal projects? It causes big frustration.'

The wellbeing of individuals depends on their self-perception, how much one believes in oneself. Identities are personal and political projects, in which one can participate to a greater or lesser extent depending on resources (Calhoun, 1994: 28). Unfortunately, there appears to be a lack of dialogue in the formulation of individual integration plans. These plans are drawn up by the municipality officers, such as social workers. In addition, it causes anxiety in the individual to see others repeating the same courses over again because nothing else is on offer. This gives the sensation of a dead end, a life that repeats itself.

'Why a person who has been in Finland for three or four years has been going through the same course in Rovala many times? This person can speak very well Finnish. When I came to Finland, I started on second level in Rovala because I had basic Finnish and there were people who had been on that course for six years. I had been in Finland for two weeks and I was in the same room with people who had been here for six years.' 
Withdrawal is a quiet way of challenging identity categories. Talking back does not always mean speaking out (Juhila, 2004: 29). Talking back can also be non-verbal, such as withdrawn body language and reserved behaviour. If the society is not open to an immigrant's own identity definitions, solitude becomes attractive. It is something that can backfire in society as a whole because it can lead to complete withdrawal and insularity.

'One of things I have been thinking is that each person has a back bag and whatever you are living you put in there. My experience as an immigrant is not just in Finland. Integration plan is more like you have to have that back bag empty, like you need to put in new stuff. It really does not matter what you have had there, have been thinking, or what you know about.'

'When we (immigrants) arrive to a new place where people want to put stuff into your bag! Everything you have to feel secure and survive in a mental way is in your bag. Then you are not going to let them know and touch it because it is sacred for you. I have noticed that people get very closed about their own culture.'

Technology has made it possible to keep in touch with old friends rather than making new ones. If one cannot find ways in which to relate to Finnish society, this option secures a social life.

'This is where the internet and technology steps in. Without that, I would be forced into a situation where I would have to socialise more. It is a bit of a distortion, a bubble. You don't have to go out, you don't need to. It is because fifteen per cent of my requirement to socialise is met by the internet. If I didn't have that I would gradually become more isolated and I would have to try to find something in a Finnish context. That holds you in a position of not doing anything about it. How are we going to develop as species when we have all technology, and what is going happen to immigration, if people can move to a different country and still stay in touch with people thousands of miles away? Then there is no requirement to integrate. You are just going to keep the relationships with people back home with Skype or whatever. Why bother to go out and make contact?'

Acceptance is the most tragic outcome of stereotyping because the views that other people have about the immigrant infiltrate who she or he is. The person accepts the position on the outside as permanent in nature. In the interview material, the different strategies were in a way played against each other. One day one can feel like withdrawal, and another day one feels confident enough to engage in conflict. 
'There has been becoming this kind of wall there what I am and what you are. This can be also be coming from the system because all immigrants are the same, like making this plan of integration to everyone in the same way. In addition, you feel like you are the same, even though you don't wanna or you don't feel like. From the start, you feel like you are at the back with the immigrants. You don't even get a break with the Finnish people. Only the teacher is Finnish.'

'You are an immigrant but you know that you are different, everybody is different, then you are in this point that you feel completely alone, Finnish people think you are from this pack of immigrants. You are not a part of a big group, you are in a minority. I have been thinking about a lot of things but I feel like that the system does not want to listen. Immigrants can feel like I am not like them, I am from the other side. I am against them if I want to do something different.'

In this above extract, the multicultural mechanisms of exclusion are well illustrated. The individual lacks the choice to locate belonging. She is afloat between different categories, unable to attach herself to the wider society, which leaves her with the sensation of loneliness, of total exclusion.

\section{CONCLUSIONS}

Despite the small sample, our findings raise important issues. There results indicate that Finnish majority can dominate interactions with non-native residents and these interactions can confine those who are not native. What emerged from the research was how national identities are constructed and the defence mechanisms that lay hidden in these processes. These mechanisms are central to the construction of the ethnic categorisation of the Other. Our findings add to the understanding of how cultural power operates from the immigrant's perspective. 'Where there is power, one can always find resistance' (Foucault, 1990). Foucault's claim is actualised in the findings. Emphases on authentic ethnic identity, undermines political and personal choices that individuals make. The findings illustrate how the participants are left in a social vacuum. Language creates certain concrete living conditions and it is crucial to examine the discourses and representations that maintain inequalities (Burr, 1995: 62-63).

The strategies discussed in this article take their toll on the individual; the only strategy that is truly rewarding to the user, is playing with categories. This strategy is reserved for those who do not physically deviate 
from the Finnish norm. The space where the negotiation of identities takes place is claustrophobic. There is some room for maneuvering, but society erects barriers that are constantly squeezed and the immigrant individual has to keep pushing to create space. Multicultural rhetoric serves to maintain national identity when modern truths about fixed identity are being eroded.

Despite the strengths of the data there are limitations as well. The narratives did not explore the backgrounds of the individuals in any great detail, which could have broadened the stories. Backgrounds are not exposed in order to protect the participants' anonymity. The number of non-native residents is small and we want to take every precaution to make sure participants cannot be identified.

\section{RECOMMENDATIONS FOR SOCIAL WORK}

In this article we aimed to shed light on how cultural power is present in everyday interactions between native and non-native residents. In Finland the cultural power of the majority is overwhelming and this poses questions also for social work. Finnish social work has potential for developing narrative approaches in the profession, since the services are at a developmental stage. The acknowledgement of subjective knowledge can motivate social workers to become advocates for immigrants' rights. At their worst, stereotypes have a dehumanising effect on identities. Those who have been dehumanized cannot be liberated by those who have dehumanized them but instead, only the oppressed can free the oppressors (Freire, 1988). Social workers need to recognize their involvement in the dehumanizing processes by practicing continuous critical reflections about their own values and understanding of the world.

\section{REFERENCES}

1. Anis, M. (2008) Sosiaalityö ja maahanmuuttajat - lastensuojelun ammattilaisten ja asiakkaiden vuorovaikutus ja tulkinnat. [Social Work and Immigrants. Interaction and interpretations among child protection professionals and clients] Väestötutkimuslaitoksen julkaisusarja D 47. Helsinki: Väestöliitto.

2. Ben-Ari, A., Strier, R. (2010) Rethinking Cultural Competence: What Can We Learn from Levinas? The British Journal of Social Work, 40 (7): 2155-2167.

3. Beresford, P., Croft, S. (2001). Service Users' Knowledges and the Social Construction of Social Work. Journal of Social Work, 1 (3): 295-316. 
4. Burr, V. (1995) An Introduction to Social Constructivism. London: Routledge.

5. Calhoun, C. (1994) Social Theory and the Politics of Identity. In: C. Calhoun (ed.). Social Theory and Politics of Identity. Oxford: Basil Blackwell, 9-36.

6. Clarke, K. (2011a) Negotiating Migrant Community Needs through Social Work Research: A Finnish Example. Qualitative Social Work, 10 (1): 8-27.

7. Clarke, K. (2011b) The Paradoxical Approach to Intimate Partner Violence in Finland. International Perspectives in Victimology, 6 (1): 9-11.

8. Curry-Stevens, A. (2011) Persuasion: Infusing Advocacy Practice with Insights from Anti-oppression Practice. Journal of Social Work, 12 (4): 345-363.

9. Montigny, G. A. J., de. (2013) The Essentialism of Whiteness: Abandoning Empirical Engagement. Journal of Social Work, 13 (6): 633-651.

10. Dominelli, L. (2012) Green Social Work. Cambridge: Polity Press.

11. Egharevba, S. (2011) Understanding the Racial Nature of Police and Immigrant Relations in Finland. The Case of Africans in Turku. Annales Universitatis Turkuensis B 331. Turku: University of Turku.

12. Foucault, M. (1990) The History of Sexuality. Volume 1. New York: Random.

13. Freire, P. (1988) Pedagogy of the Oppressed. New York: Continuum.

14. Gubrium, J. F., Holstein J. A. (2003) From the Individual Interviewer to the Interview Society: In: J. F Gubrium, J. A. Holstein (eds.) Postmodern Interviewing. Thousand Oaks: Sage, 21-49.

15. Hall, S. (1997) The Spectacle of the Other. In: S. Hall (ed.). Representations Cultural Representations and Signifying Practices. London: Sage, 225-279.

16. Hall, S. (1999) Identiteetti. [Identity]. In: M. Lehtonen, J. Herkman (eds.). Tampere: Vastapaino.

17. Harinen, P., H. Niemelä (2005) Nuorten maahanmuuttajien elämää ja kokemuksia [Immigrant Youths' Life Experiences in Finland]. In: S. Paananen (ed.). Maahanmuuttajien elämää Suomessa. [The Lives of Immigrants in Finland]. Helsinki: Tilastokeskus, 157-172.

18. Horsti, K. (2009) Kyllä Suomeen yksi nainen mahtuu! Turvapaikanhakijat uhreina ja uhkana suomalaisessa julkisuudessa [One Woman surely fits into Finland! Asylum seekers as victims and as threats in Finnish public discourses]. In: S. Keskinen, A. Rastas, S. Tuori (eds.). En ole rasisti mutta... [I'm not a racist, but...]. Tampere: Vastapaino, 77-86.

19. Huttunen, L. (2004) Kasvoton ulkomaalainen ja kokonainen ihminen: marginalisoiva kategorisointi ja maahanmuuttajien vastastrategiat [Faceless Foreigner and Wholly Human: Marginalising Categories and Immigrants' Counterstrategies]. In: A. Jokinen, L. Huttunen, A. Kulmala (eds.). Puhua vastaan ja vaieta [Talking back and silencing]. Helsinki: Gaudeamus, 134-154.

20. Johansson, I. M. (2011) The Multicultural Paradox: The Challenge of Accommodating both Power and Trust in Child Protection. International Social Work, 54 (4): 535-549. 
21. Juhila K., and Abrams L. (2011) Constructing identities in social work setting. Qualitative Social Work, 10 (3): 277-292.

22. Juhila, K. (2006) Sosiaalityöntekijöinä ja asiakkaina - Sosiaalityön yhteiskunnalliset tehtävät ja paikat [As Social Workers and Clients - the Societal Functions and Places of Social Work]. Tampere: Vastapaino.

23. Juhila, K. (2004) Leimattu identiteetti ja vastapuhe [Stigmatized Identities and Talking back]. In: A. Jokinen, L. Huttunen, A. Kulmala (eds.). Puhua vastaan ja vaieta [Talking back and silencing]. Helsinki: Gaudeamus, 20-32.

24. Keddell, E. (2009) Narrative as Identity: Postmodernism, Multiple Ethnicities, and Narrative Practice Approaches in Social Work. Journal of Ethnic \& Cultural Diversity in Social Work, 18 (3): 221-241.

25. Keskinen, S. (2011) Troublesome Differences - Dealing with Gendered Violence, Ethnicity and 'Race' in the Finnish Welfare State. Journal of Scandinavian Studies in Criminology and Crime Prevention, 12 (2): 153-172.

26. Masocha, S. (2014) Construction of the 'other' in social workers' discourses of asylum seekers. Journal of Social Work. Published online before print September 15, 2014 [seen 2011 2014]. doi: 10.1177/1468017314549502

27. McLaughlin, H. (2009) What's in a Name: 'Client', 'Patient', 'Customer', 'Consumer', 'Expert by Experience', 'Service User' - What's Next? British Journal of Social Work, 39 (6): 1101-1117.

28. Park, Y. (2005) Culture as Deficit - A Critical Discourse Analysis of the Concept of Culture in Contemporary Social Work Discourse. Journal of Sociology \& Social Welfare, 32 (3): 11-33.

29. Ploesser, M., Mecheril. P. (2012) Neglect - Recognition - Deconstruction: Approaches to Otherness in Social Work. International Social Work, 55 (6): 794-808.

30. Statistics Finland 2013. Population survey: Foreigners in Finland (e-publication), updated 22.3.2013 [seen 111 2013]. Online access: http://www.stat. fi/tup/suoluk/suoluk_vaesto_en.html

31. Suokonautio, M. (2008) Palapelinpalat paikoilleen - Maahanmuuttajien kokemuksia kotoutumiskoulutuksesta ja ehdotuksia sen kehittämiseksi. [Placing the Pieces of the Puzzle - Immigrants' Experiences of Integration Education and Ideas for Improvement]. Sosiaalityön ammatillinen lisensiaattityö. Jyväskylän yliopisto. Yhteiskuntatieteiden ja filosofian laitos. Sutela, H. (2005). Maahanmuuttajat palkkatyössä [Immigrants in the Paid Work]. In: S. Paananen (ed.). Maahanmuuttajien elämää Suomessa [The Lives of Immigrants in Finland]. Helsinki: Tilastokeskus, 83-110.

32. Suurpää, L. (2002) Erilaisuuden hierarkiat [Hierachies of Difference]. Julkaisuja, 28. Nuorisotutkimusverkosto. Helsinki.

33. Tigervall, C., Hübinette, T. (2010) Adoption with Complications: Conversations with Adoptees and Adoptive Parents on Everyday Racism and Ethnic Identity. International Social Worki, 53 (4): 489-509. 
34. Vennik, F. D., Adams, S. A., Faber, M. J., Putters, K. (2014) Expert and Experiential Knowledge in the Same Place: Patients' Experiences with online Communities connecting Patients and Health Professionals. Patient education and counseling, 95 (2): 265-270.

35. Walker, S. (2005) Towards Culturally Competent Practice in Child and Adolescent Mental Health. International Social Work, 48 (1): 49-62.

36. Young, S., Zubrzycki, J. (2011) Educating Australian social workers in the post-Apology era: The potential offered by a 'Whiteness' lens'. Journal of Social Work, 11 (2): 159-173.

\section{SANTRAUKA}

\section{METANT IŠŠŪKI DOMINUOJANČIAM ETNIŠKUMO DISKURSUI. SUOMIJOS ATVEJIS}

Straipsnyje aptariami kokybinio tyrimo, kuri atliekant analizuoti ne etninių suomių, gyvenančių Suomijoje, naratyvai, rezultatai. Dauguma šalies gyventojų yra gimę Suomijoje, tad šalis sudaro įdomų konteksta, kuriame tyrinejjama galios dinamika, konstruojanti etnini identitetą. Tyrimo tikslas buvo suprasti imigrantų kasdienio gyvenimo patirtis. Identiteto kategorijos yra svarbūs žymenys, atskiriantys įtrauktį ir atskirtį, o tai svarbu ir socialiniam darbui. Iš kokybinės stereotipų analizès matyti imigrantų subjektyvi patirtis. Rezultatai rodo socialinės atskirties etniškumo pagrindu elementus. Tam tikros imigrantų charakteristikos ir su jais susiję lūkesčiai ịtvirtina jų identitetą. Kuo labiau žmogus yra vertinamas kaip nukrypstantis nuo Suomijoje priimtų normų, tuo didesni jo atžvilgiu lūkesčiai. Tyrimo dalyvių naratyvai parodo improvizuotas strategijas siekiant susitvarkyti (ang. cope) su iš anksto nustatytomis etninėmis kategorijomis. Šios strategijos yra paaiškinimas, žaidimas su kategorijomis, įsitraukimas ị konflikta, atsisakymas ir prièmimas Kitokio vaidmens. Naratyvų dinamika pabrèžè naratyvinio požiūrio pritaikymo socialinio darbo praktikoje svarbą ir tai, kaip svarbu tyrinèti ne etninių suomių kasdienio gyvenimo patirtis. Etniniai suomiai gali dominuoti sąveikoje su ne suomiais gyventojais, ir tai svarbu socialinio darbo praktikai. Socialiniai darbuotojai, atstovaudami daugumai, turi būti sąmoningi ir jautrūs klientų individualios situacijos supratimui. 